\title{
Commentary: "Candidemia in tertiary hospitals in northeastern Brazil"
}

\author{
Sylvia Lemos Hinrichsen'
}

'Tropical Diseases Department, Universidade Federal de Pernambuco, Cidade Universitária s/n, Recife-Pernambuco, Brazil

Article Info

\section{Article Notes}

Received: February 28, 2019

Accepted: May 10, 2019

\section{*Correspondence:}

Sylvia Lemos Hinrichsen, Tropical Diseases Department, Universidade Federal de Pernambuco, Cidade

Universitária s/n, Recife-Pernambuco, Brazil; Email: sylviahinrichsen@hotmail.com.

(C) 2019 Hinrichsen SL. This article is distributed under the terms of the Creative Commons Attribution 4.0 International License.
The article "Candidemia in tertiary hospitals in northeastern Brazil" is devoted to an important problem in tertiary hospitals where there is the availability of all kinds of super specialities. Candida infections have increased significantly in recent decades and this has been associated to the rise of morbidity and mortality in critically ill patients, as well as elevated hospital costs and the extending of the hospitalization period ${ }^{1,2}$. Candidemia is responsible for almost $80 \%$ of all hospital related fungal infections, known as Candida spp. and it is a common isolated pathogen that leads to nosocomial Sepsis in adults and frequently in neonates(newborns) ${ }^{2-6}$.

The main risk factors associated with candidemia are: prolonged hospital stays, neutropenia, parenteral nutrition, bladder / central venous catheters, mechanical ventilation, the colonization of multiple anatomical sites by yeasts, extreme ages (infants with less than one year or in the elderly of older than 65 years) and also the use of broad-spectrum antibiotics ${ }^{7,8}$.

In a 20-year period of study in a Brazilian tertiary care teaching hospital, it was observed that the incidence of candidemia did not change significantly over time ${ }^{3}$. The results showed that there was a slight increase in the median age of patients with candidemia and the occurrence of some factors such as mechanical ventilation and the use of vasoactive amines and corticosteroids increased over time $^{3}$. The severity of illness increased, and the mortality was high, and did not change significantly in the three study periods ${ }^{3}$.

The species distribution did not change over time, with $C$. albicans, C. tropicalis and C. parapsilosis accounting for over $80 \%$ of cases of candidemia, and the proportion of patients receiving antifungal therapy increased between periods 1 and 2 . The time from candidemia to the initiation of treatment decreased over time, leading to a change in therapeutic practices, with a reduction in the use of deoxycholate amphotericin B and an increase in the use of echinocandins as primary therapy ${ }^{3}$.

Candida albicans continues to be the most frequent cause of candidemia at large tertiary hospitals but antifungal resistance is a growing concern taking into account non-albicans Candida species ${ }^{5}$.

An epidemiologic study of candidemia in Latin America showed a high incidence of candidemia, high percentages in children, typical species distribution, with C. albicans, C. parapsilosis and C. tropicalis accounting for the majority of episodes, and low resistance rates ${ }^{9}$. Prognostic factors and historical trends in the epidemiology of candidemia in critically ill patients of five Brazilian multicenter studies over a 9-year period showed a 30-day crude mortality rate 
of $75.3 \%$ in the public hospitals and $65.3 \%$ in private institutions $(p=0.006)$ and its incidence rate in Brazil averages 2.49 per 1000 hospital admissions ${ }^{9,10}$. In the northeast region of Brazil, the matter becomes even more alarming as there are few published studies ${ }^{4,11-13}$.

In this framework, our studies have been focused on understanding candidemia in tertiary hospitals in northeastern Brazil. We conducted a prospective, observational, laboratory-based study on candidemia to investigate the incidence of candidemia, species distribution and clinical conditions between September 2003 and March 2004 in a private tertiary hospital in Recife, northeastern Brazil. Cases of candidemia were defined as occurrences of the isolation of Candida spp. from blood cultures. In these studies, Candida isolates were not identified using molecular methods ${ }^{11,12}$. The incidence rate was calculated per 1,000 admissions. A total of 5,532 patients were admitted to the hospital during the study period, and 1,745 blood cultures were processed ${ }^{11}$. The incidence rate of candidemia was 3.9 episodes per 1,000 admissions ${ }^{11}$. Non-albicans species accounted for more than $50 \%$ of the cases, and Candida parapsilosis (33\%) and Candida tropicalis (24\%) predominated. Eleven (61\%) patients died ${ }^{11}$. The incidence of candidemia was higher than that observed in other multicenter studies ${ }^{11,13-15}$. Candidemia was caused predominantly by non-albicans species ${ }^{11,12}$.

\section{References}

1. Giolo MP, Svidzinski TIE. Physiopathogenesis, epidemiology and laboratory diagnosis of candidemia. J Bras Patol Med Lab. 2010; 46(3): 225-234.

2. Guinea, J. Global trends in the distribution of Candida species causing candidemia. Clin Microbiol Infect. 2014; 20(6): 5-10.

3. Braga PR, Cruz IL, Ortiz I, et al. Secular trends of candidemia at a Brazilian tertiary care teaching hospital. Braz J Infect Dis [online] 2018; vol.22 n.4: 273-277. Available: <http://www.scielo.br/scielo. php?script=sci_arttext\&pid=S1413-86702018000400273\&lng=pt\&n rm=iso\&tlng=en > In: 04/22/2019.
4. Barberino MG, Silva N, Rebouças C, et al. Evaluation of blood stream infections by candida in three tertiary hospitals in Salvador, Brazil: a case-control study. Braz J Infect Dis. 2006; 10(1): 36-40.

5. Lin S, Chen R, Zhu S, et al. Candidemia in Adults at a Tertiary Hospital in China: Clinical Characteristics, Species Distribution, Resistance, and Outcomes. Mycopathologia. 2018 Aug; 183(4): 679-689. Available: <https://www.ncbi.nlm.nih.gov/pubmed/29572768>. In: 04/22/2019.

6. Bassetti M, Righi E, Ansaldi F, et al. A multicenter study of septic shock due to candidemia: outcomes and predictors of mortality. Intensive Care Med. 2014; 40: 839-45.

7. Cornistein W, Mora A, Orellana N, et al. Candida: epidemiologia y factores de riesgo para espécies no albicans. Enferm Infecc Microbiol Clin. 2013; 31(6): 380-4.

8. França JCB, Ribeiro CEL, Queiroz-Telles F. Candidemia em um hospital terciário brasileiro: incidência, freqüência das diferentes espécies, fatores de risco e suscetibilidade aos antifúngicos. Rev Soc Bras Med Trop. 2008; 41: 23-28.

9. Nucci M, Queiroz-Telles F, Alvarado-Matute T, et al. Epidemiology of candidemia in Latin America: a laboratory-based survey. PLoS One. 2013; 8(3): e59373.

10. Colombo AL, Guimarães T, Sukienik T, et al. Prognostic factors and historical trends in the epidemiology of candidemia in critically ill patients: an analysis of five multicenter centers sequentially conducted over a 9-year period. Intensive Care Med. 2014; 40: 148998.

11. Hinrichsen SL, Falcão E, Vilella TAS, et al. Candidemia in a tertiary hospital in northeastern Brazil. Rev Soc Bras Med Trop. 2008; 41(4): 394-8.

12. Hinrichsen SL, Falcão E, Vilella TAS, et al. Candida isolates in tertiary hospitals in northeastern Brazil. Braz J Microbiol. 2009; 40(2): 325-8.

13. Medrano DJA, Brilhante RSN, Cordeiro RA, et al. Candidemia in a Brazilian hospital: the importance of Candida parapsilosis. Rev Inst Med Trop. 2006; 48(1): 17-20.

14. Wisplinghoff $\mathrm{H}$, Bischoff T, Tallent SM, et al. Nosocomial bloodstream infections in US hospitals: analysis of 24.179 cases from a prospective nationwide surveillance study. Clinical Infectious Diseases. 2004; 39: 309-317.

15. Colombo AL, Nucci M, Park BJ, et al. Brazilian Network Candidemia Study. Epidemiology of candidemia in Brazil: a nationwide sentinel surveillance of candidemia in eleven medical centers. Journal of Clinical Microbiology. 2006; 44: 2816-2823. 